\title{
ANALYSIS OF POWER EQUIPMENT LEVEL ON THE EXAMPLE OF FARM TRACTORS IN SELECTED FARMS OF PRZEWORSK PROVINCE
}

\author{
Sławomir Juściński*, Wiesław Piekarski, Zdzisław Chomik \\ Department of Power Energy and Transport Means, University of Life Sciences in Lublin \\ ${ }^{*}$ Corresponding author: e-mail: slawomir.juscinski@up.lublin.pl
}

\begin{tabular}{|c|c|}
\hline ARTICLE INFO & ABSTRACT \\
\hline $\begin{array}{l}\text { Article history: } \\
\text { Received: February } 2017 \\
\text { Received in the revised form: } \\
\text { March } 2017 \\
\text { Accepted: June } 2017 \\
\end{array}$ & \multirow{2}{*}{$\begin{array}{l}\text { Decisions concerning investments in farm tractors is a significant } \\
\text { problem of modern agricultural production. Ensuring efficient } \\
\text { performance of agrotechnical treatments and a rational level of use of } \\
\text { tractors in the aspect of exploitation costs are a derivative of the power } \\
\text { equipment level in a farm. The paper presents studies carried out in } 31 \\
\text { selected farms, which run production on the total acreage of } 937 \text { ha of } \\
\text { agricultural land (AL) and exploit } 70 \text { tractors. Analysis covered } \\
\text { information on: area of farms, number and power of used tractors, } \\
\text { investments in technical equipment concerning purchase of farm } \\
\text { tractors and a production profile. In the investigated farms at the } \\
\text { average per } 100 \text { ha of the agricultural land area there was } 7.47 \\
\text { tractors, 90\% of respondents actively used subsidies available from } \\
\text { the EU structural funds. A high energy equipment level was } \\
\text { determined in particular in farm with a smaller acreage. Over } 87 \% \text { of } \\
\text { farm used more than one tractor and the age of the third each did not } \\
\text { exceed six years. }\end{array}$} \\
\hline $\begin{array}{l}\text { Key words: } \\
\text { farm tractor, } \\
\text { energy equipment level }\end{array}$ & \\
\hline
\end{tabular}

\section{Introduction}

Poland's accession to European Union has started operations related to modernization of the national agricultural production (Lorencowicz, 2008). In the recent several years domestic agriculture has undergone multi-directional and extensive changes in particular in the context of technical equipment. The technical infrastructure issue was multifaceted since in the categories of amount it was favourable due to a high number of owned tractors and machines but the age structure proved a considerable often border technical and economic wear (Lorencowicz, 2010; Pawlak, 2007; Pawlak, 2011; Piwowar, 2012).

Extension of exploitation of old equipment as a rule increased the frequency of repairs and renovations and generated high variable costs (Juściński and Chomik 2016). During Poland's accession to the EU per 100 ha of agricultural land there were 8.5 tractors; age of a statistical tractor used in agriculture was over 20 years and its power was $32 \mathrm{~kW}$ (Powszechny Spis Rolny, 2002). A great number of tractors and farm machines accompanied by a greater number of small farms resulted in low annual use.

Agricultural production in order to be competitive at a market needs modern and efficient machines and reliable tractors. Thus, purchase of new tractors in case of investments 
in modernization of technical equipment of farms was a priority. Tractors constitute the main source of driving power and traction power of the owing power of machines and devices (Pawlak, 2012; Skudlarski, 2006; Tabor and Raczkowska-Chmaj, 2012). Financial possibilities of farms decide on the scope and level of investment in technical equipment (Czarnocki et al., 2011; Kowalczyk, 2008; Kwaśniewski et al., 2011). EU funds significantly modified an unfavourable economic situation in the national agriculture. In many cases they have become a basis for a decision on purchase of technical measures. With a financial support of subsequent editions of EU funds including as follows: Special Accession Program for Agriculture and Rural Areas (SAPARD), Sector Operational Program (SPO) Restructuring and modernization of food sector and development of rural areas and Rural Areas Development Plan. Thanks to these programs restructuring of the domestic agriculture and modernization of the technical equipment of particular farms was carried out (Juściński, 2012a). Measures which may be obtained from subsequent programs created as a part of Structural Funds of the European Union enables, inter alia, modernization of technical equipment of farms and area subsidies, subsidies to products and aid for young farmers (Malaga-Toboła, 2009; Wójcicki, 2011; Wójcicki and Kurek, 2011). The quantity, quality and age structure of the market of used tractors in Poland constituted a challenge for logistic systems of global producers of agricultural machines who by treating Poland as a new outlet, created a network of authorized distribution and service points in a short time (Juściński and Piekarski, 2008; Juściński, 2012b).

A relatively high price of modern tractors and agricultural farms requires ensuring for them a relevant labour front since a low level of use in a year generates an increase of unit fixed costs and this leads to the decrease of profitability of production. The sum of purchase costs, technical service and exploitation costs of tractors constitutes the main group of production mechanization costs (Grześ, 2008; Kapela and Czarnocki, 2011; Kocira and Parafiniuk, 2006; Kowalik and Grześ, 2006).

It should be emphasised that restructuring of the national agriculture and modernization of technical equipment of farms on the area of particular voivodeships had a varied scope and nature and did not lead to equalization of differences in the agrarian structure and level of technical equipment. The problem of restructuring is particularly related to small farms which carry out a multi-trend and low-commodity production and functioning in difficult geographical conditions (Szuk, 2009; Wasąg and Tarasińska, 2010). It generates the need for research with regard to technical equipment of a farm and analysis of obtained results in order to present and assess the level of changes of the machinery park in farms in particular regions of the country.

\section{Objective, scope and methodology of research}

The objective of the paper was to obtain information on the agricultural production which is carried out in the aspect of use of one of the basic elements of technical equipment of farm namely agricultural tractors. Analysis included many issues among which information on the following was highlighted:

- area of agricultural land (AL) of the investigated farms,

- production profile,

- number and power of used tractors,

_ investments in technical equipment concerning purchase of tractors. 
Analysis of power...

Analysis of the collected information constituted the basis for determination of the energy equipment level on the example of the total power of engines in tractors used in the selected farms of Przeworsk province. The total power of engines was referred to the AL area of the investigated farms. The paper defines and evaluates the structure of the sources of financing at the purchase of tractors. Correlation between the area of farms in ha of AL and the power saturation related to the power of farm tractors engines was statistically developed. The research was carried out in 2015 in the form of a direct survey among farms cooperating with the Provincial Unit for Agricultural Advice in Przeworsk. Surveys with owners of 32 farms, which actively participated in the restructuring of the owned machinery park were randomly selected and carried out.

\section{Research results}

Agriculture in Podkarpackie Voivodeship is varied with regard to regions on account of the area of farms and type of production intensity. On the area of Podkarpackie Voivodeship $11.5 \%$ of farms from the total number of farms in the country, which carry out production on $4.5 \%$ of the total area of agricultural land, function. In the majority of 25 provinces, family farms with a multi-trend production with low commodity prevail. Area structure of farms is unfavourable in the aspect of free market requirements since farms with a small and very small area of agricultural land prevail.

The research which was carried out allowed setting in table 1 data which define the selected farms in Przeworsk Province.

The average area of an individual farm in the group above 1 ha was in Podkarpackie Voivodeship 4.56 ha and in Przeworsk Province 3.4 ha. Private Sector prevails and agricultural activity is carried out by 10780 farms. Unfavourable geographical conditions cause that on the area of Przeworsk Province over $83 \%$ of farms has an acreage within 1-5 ha. It constitutes a key impediment in realization of agricultural production to a greater scale (Powszechny Spis Rolny, 2010).

The average area of agricultural land (AL) statistically per 1 tractor in 2010 decreased in comparison to 2010 and was 6.35 ha. In comparison in the country average area of AL per 1 tractor was 10.57 ha. In Podkarpackie Voivodeship agricultural farms had 93900 tractors (Powszechny Spis Rolny 2010). There is also variability with regard to the average power of tractors: $47 \mathrm{~kW}$ in northern and western Poland's voivodeships and almost $30 \mathrm{~kW}$ in Podkarpackie Voivodeship (Lorencowicz, 2011). In the country per 100 farms which carry out agricultural activity there were 77.5 tractors. A considerably lower level of equipment of farms in tractors was reported in Podkarpackie Voivodeship where at the average there were 48.9 tractors per 100 farm. On the other hand, in Przeworsk Province, farms had 6995 tractors namely per 100 farms there were 64.8 tractors.

The group of randomly selected farms differed with the size of acreage and production trend. The smallest investigated farm had agricultural land with the area of 9.2 ha and the biggest one 120 ha. Generally these were farms with a bigger area of cultivation from the average acreage on the territory of Przeworsk Province. Farms covered with the research carried out production on the total acreage of 937 ha and differed with the production profile. Figure 1 presents the production type structure in farms 
Sławomir Juściński, Wiesław Piekarski, Zdzisław Chomik

Table 1.

List of data defining investigated farms in Przeworsk Province

\begin{tabular}{|c|c|c|c|c|c|}
\hline Item & $\begin{array}{c}\text { Farm area } \\
\text { (ha AL) }\end{array}$ & $\begin{array}{l}\text { Production } \\
\text { profile }\end{array}$ & $\begin{array}{l}\text { Number of } \\
\text { used tractors } \\
\text { (pcs) }\end{array}$ & $\begin{array}{c}\text { Total power of } \\
\text { used tractors } \\
(\mathrm{kW})\end{array}$ & $\begin{array}{c}\text { Power } \\
\text { equipment level } \\
\left(\mathrm{kW} \cdot \mathrm{ha}^{-1}\right)\end{array}$ \\
\hline 1 & 9,2 & B & 1 & 34,5 & 3,7 \\
\hline 2 & 11,1 & A & 2 & 92,7 & 8,3 \\
\hline 3 & 11,1 & A & 2 & 92,7 & 8,3 \\
\hline 4 & 11,2 & $A+B$ & 1 & 38 & 3,4 \\
\hline 5 & 11,2 & $A+B$ & 1 & 38,2 & 3,4 \\
\hline 6 & 12,2 & A & 2 & 100 & 8,1 \\
\hline 7 & 12,3 & A & 2 & 100 & 8,1 \\
\hline 8 & 14,9 & $A+B$ & 2 & 90,5 & 6 \\
\hline 9 & 15,5 & A & 2 & 60,3 & 3,9 \\
\hline 10 & 16,4 & $A+B$ & 2 & 102 & 6,2 \\
\hline 11 & 16,4 & A & 2 & 73,6 & 4,5 \\
\hline 12 & 16,7 & C & 3 & 108,2 & 6,5 \\
\hline 13 & 19 & B & 2 & 121,4 & 6,3 \\
\hline 14 & 19,1 & $A+B$ & 1 & 58,9 & 3,08 \\
\hline 15 & 20 & A & 3 & 168 & 8,4 \\
\hline 16 & 20,1 & $A+B$ & 2 & 93,5 & 4,6 \\
\hline 17 & 20,1 & $A+B$ & 2 & 93,4 & 4,6 \\
\hline 18 & 22,6 & A & 2 & 104,5 & 4,6 \\
\hline 19 & 23,7 & $A+B$ & 3 & 127 & 5,3 \\
\hline 20 & 26,4 & A & 2 & 58,1 & 2,2 \\
\hline 21 & 27,4 & A & 2 & 130 & 4,7 \\
\hline 22 & 27,4 & A & 2 & 130,2 & 4,7 \\
\hline 23 & 31,9 & $A+B$ & 2 & 97 & 3 \\
\hline 24 & 35,3 & B & 3 & 159,7 & 4,5 \\
\hline 25 & 40 & A & 3 & 285 & 7,1 \\
\hline 26 & 41,6 & A & 2 & 154,6 & 3,7 \\
\hline 27 & 44,6 & A & 3 & 211,2 & 4,7 \\
\hline 28 & 44,7 & $A+B$ & 3 & 122 & 2,7 \\
\hline 29 & 74,9 & B & 3 & 156 & 2,1 \\
\hline 30 & 120 & A & 5 & 340 & 2,8 \\
\hline 31 & 120 & A & 3 & 305,5 & 2,5 \\
\hline $\begin{array}{l}\text { Average } \\
\text { value }\end{array}$ & 30,2 & - & 2,3 & 124,1 & 4,9 \\
\hline
\end{tabular}

Notice: Production profile: A - plant production, $B$ - animal production (dairy cows breeding), $C$ - horticultural production 


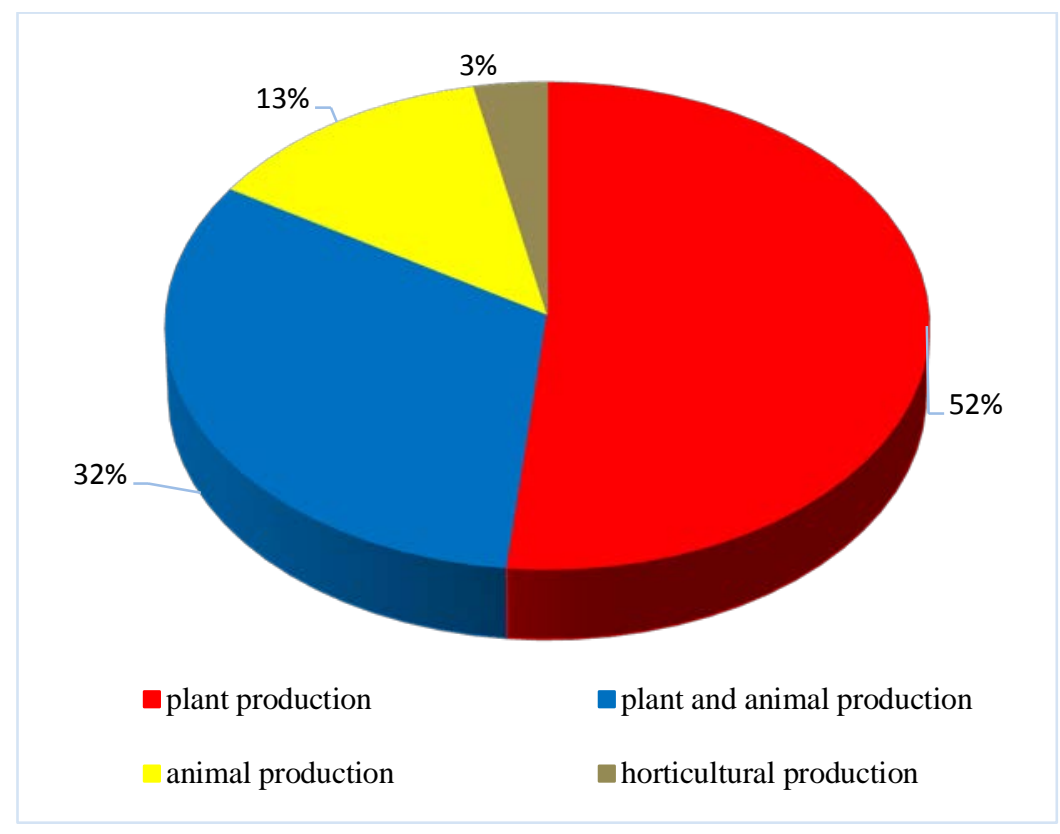

Figure 1. Agricultural production structure in investigated farms on the territory of Przeworsk Province

Almost half of farms carried out plant production only, every third one carried out plant and animal production and only every eighth one animal production (dairy cows breeding).

In farms covered by the research in total 70 tractors were used, among which over half were old tractors of the Polish made Ursus and Zetor tractors imported in the 20th century. Owing a great group of old vehicles results from the saturation level of agriculture with technical measures in the last century and low degree of withdrawing from exploitation even old tractors. The fact that $94 \%$ of the investigated agricultural farmers has at least one new tractor, whose age does not exceed 6 years proves a high level of investments for modernization of the machinery park. Generally, the level of equipment in agricultural farms was high: $100 \%$ of farms had at least one tractor, $87.1 \%$ two tractors and $29 \%$ of farms used three and more tractors. At the average per 100 ha of AL there were 7.47 of farms.

The level of power of agricultural tractors expressed in $\mathrm{kW}$, used in the selected farms is presented in figure 2. Tractors from two ranges of power prevailed: up to $50 \mathrm{~kW}$ (31\%) and from 50 to $100 \mathrm{~kW}$ (31\%).

The level of energy equipment in $\mathrm{kW} \cdot \mathrm{ha}^{-1}$ was varied in relation to the area of a farm which is presented in figure 3 . The biggest number of farms (39\%) had power within 2 to $4 \mathrm{~kW} \cdot \mathrm{ha}^{-1}$, and $29 \%$ of farms had the evaluated index within 4 to $6 \mathrm{~kW} \cdot \mathrm{ha}^{-1}$. 
Sławomir Juściński, Wiesław Piekarski, Zdzisław Chomik

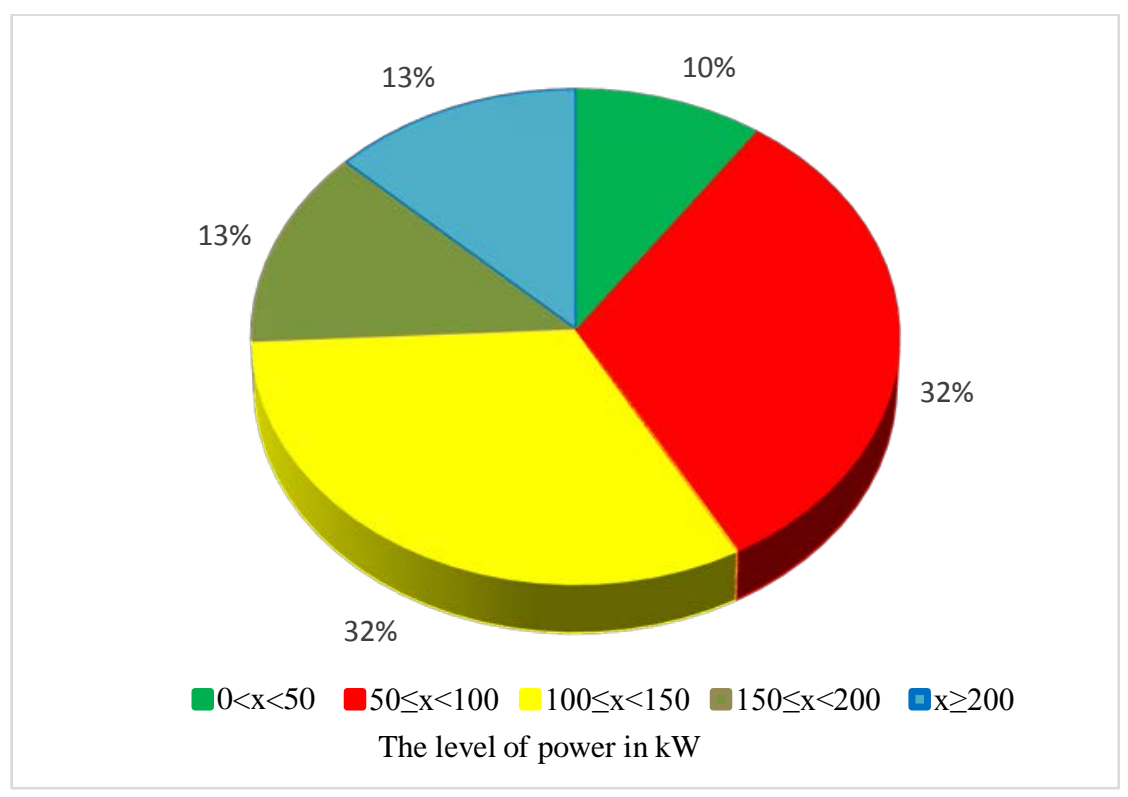

Figure 2. The level of power in $k W$ of agricultural tractors engines used in the investigated farms

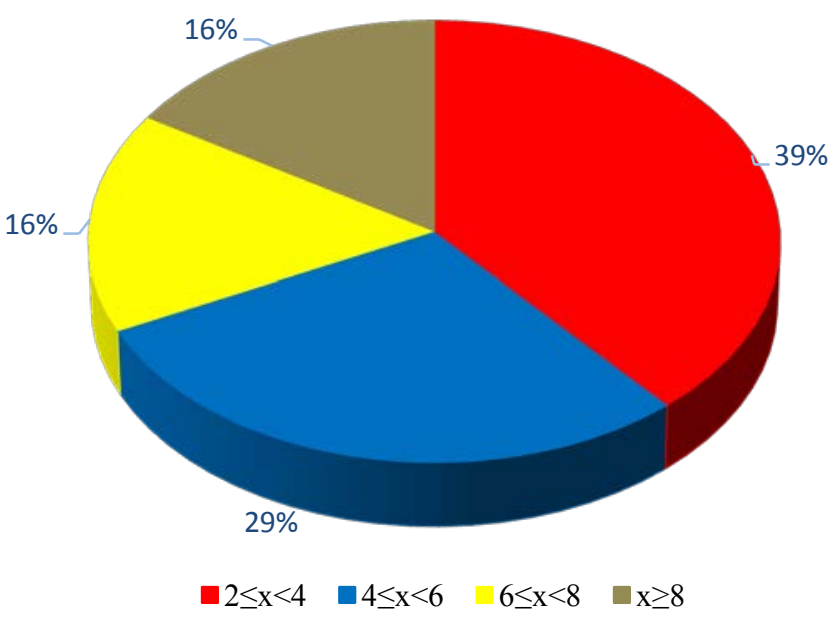

Energy equipment level in $\mathrm{kW} \cdot \mathrm{ha}^{-1}$

Figure 3. Energy equipment level in $\mathrm{kW} \cdot \mathrm{ha}^{-1}$ on the example of the power of farm tractors in investigated farms 
Analysis of power...

The energy equipment level decreased in farms along with the increase of the agricultural land area. The highest energy concentration which was at the average $6.01 \mathrm{~kW} \cdot \mathrm{ha}^{-1}$ was found in the group of farms with the area of 10-20 ha and in several cases it exceeded $8 \mathrm{~kW} \cdot \mathrm{ha}^{-1}$. Almost 4 -fold difference in the level of power saturation resulting from the number and power of tractors in particular farms should be emphasised. From the economic point of view the level of power equipment in smaller-AL acreage farms was irrational. Some farms had such a significant surplus of power that searching for possibilities of its use for example on providing mechanization services would be justified. However, small interest of farmers in Przeworsk Province with various form of team use of machines or their paid lease is a problem.

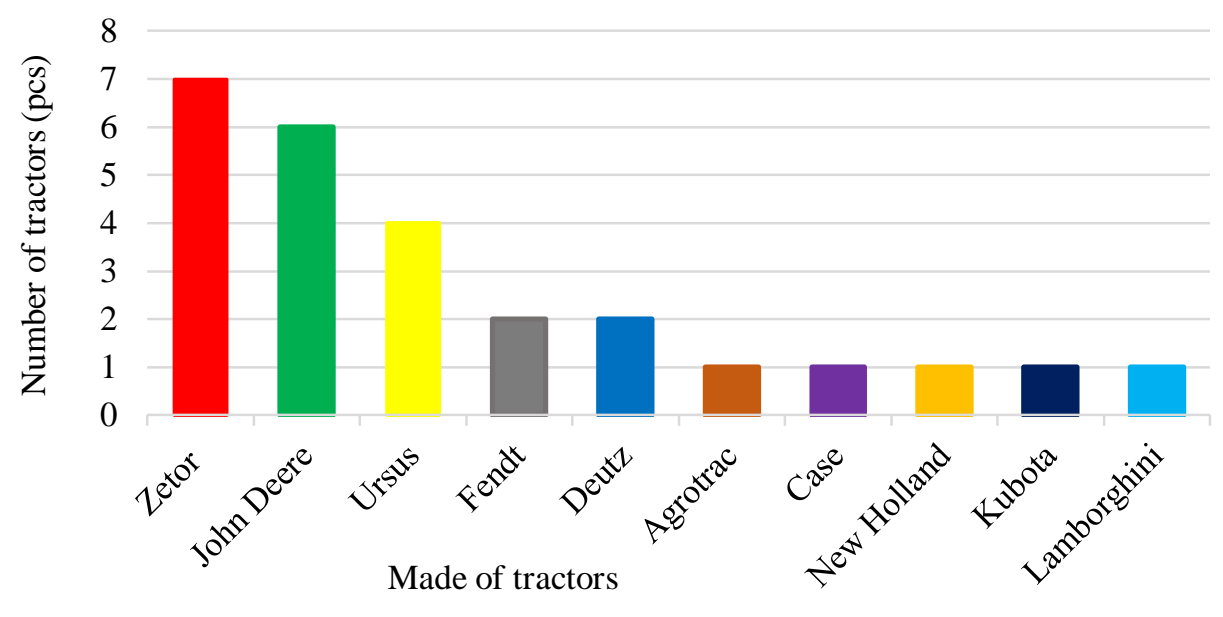

Figure 4. Quantity and type characteristics of tractors purchased in the investigated farms in 2013-2015

26 new tractors were purchased in total in the investigated farms in 2013-2015. Leading brands among the purchased tractors are: Zetor, John Deere and Ursus. Tractors were mainly purchased with funds from the European Union programs granted through the Agency of Restructuring and Modernization of Agriculture which is confirmed by the structure of funding sources for investments in farms, presented in figure 5 .

Figure 6 presents average number of tractors with regard to the area of farms in ha of AL. Increase of the number of owned tractors along with the increase of the area was reported but it was not the increase which was directly proportional to the acreage. AL area per one tractor in big farms was bigger as a rule in smaller farms and exceeded the domestic average. 
Sławomir Juściński, Wiesław Piekarski, Zdzisław Chomik

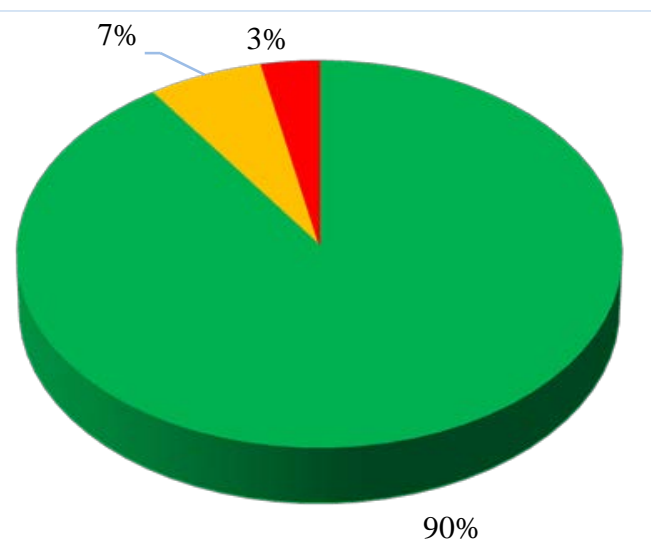

- Funds from Agency for Restructuring and Modernization of Agriculture

Preferential loans

No investments

Figure 5. Funding sources structure at the purchase of tractors in investigated farms

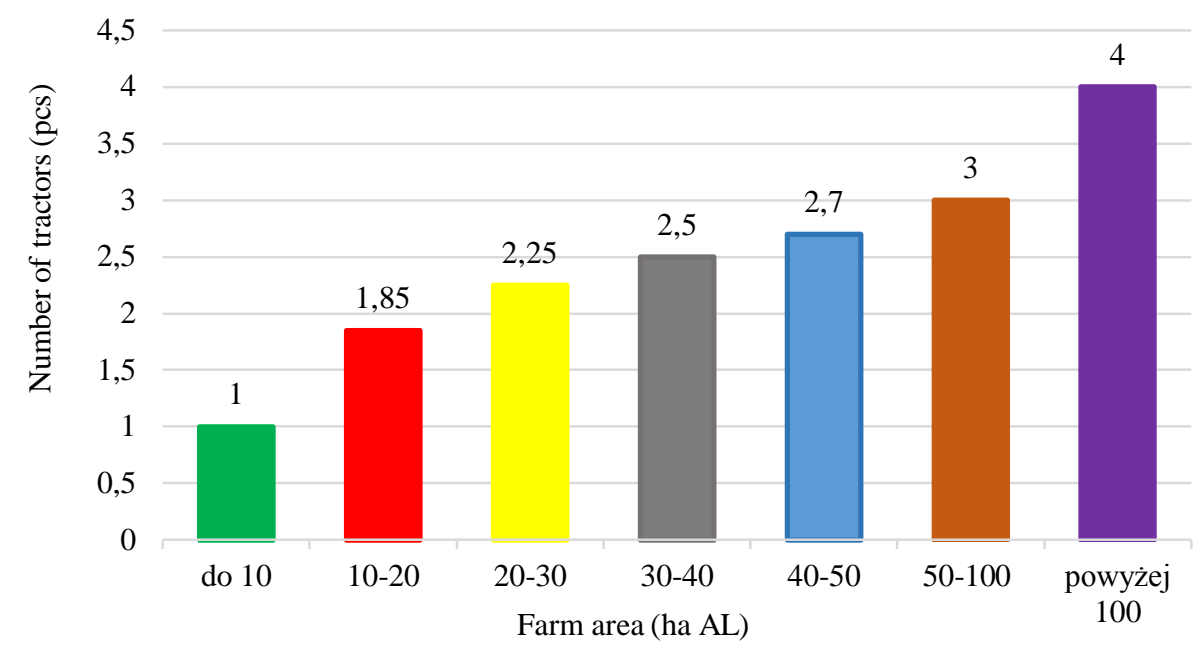

Figure 6. Average number of used tractors in relation to farm area (ha $A L$ ) 
Analysis of power...

Figure 7 presents correlation between the area of farms in ha of AL and the energy concentration related to the power of farm tractors engines.

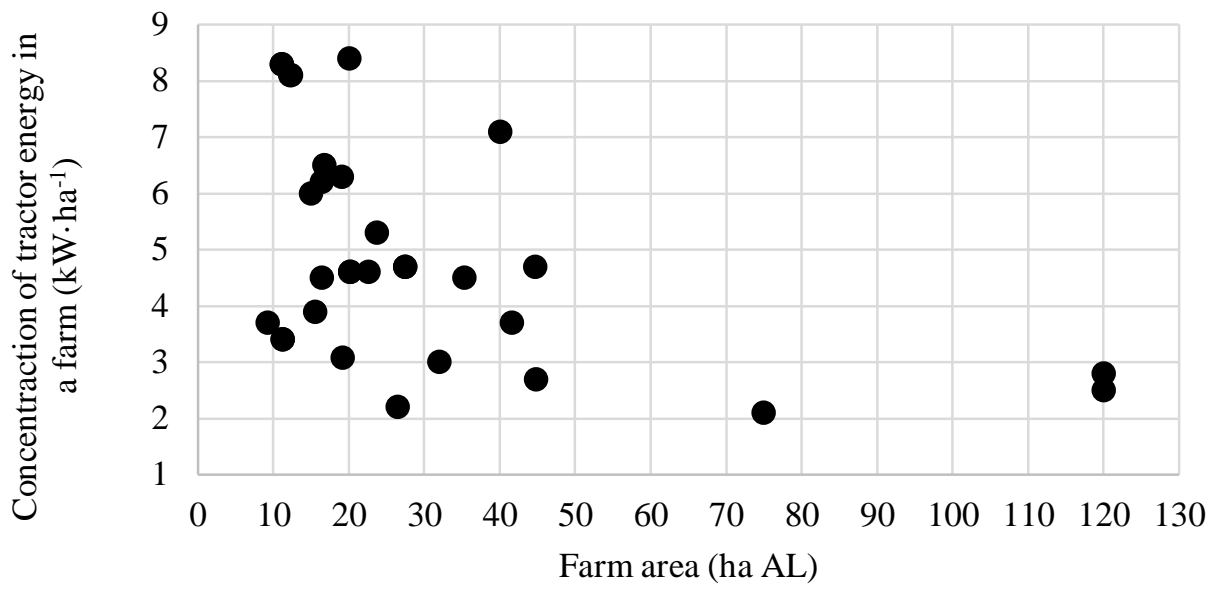

Figure 7. Correlation between the farm area (ha $A L$ ) and energy concentration in farm tractors

Pearson correlation coefficient between the agricultural land area and energy concentration of a farm was calculated with $\mathrm{R}$ program version for Windows. The coefficient is 0.4863323 , which means that there is a weak negative correlation between the investigated numbers. In farms along with the increase of the area of agricultural land, power concentration related to the power equipment level with tractors decreased.

\section{Conclusions}

1. Realization of subsequent EU programs which aim at restructuring of agriculture and modernization of farms in Poland caused positive and visible changes. In 31 investigated farms 26 new tractors were purchased in total. The fact that $94 \%$ of the investigated agricultural farmers has at least one new tractor, whose age does not exceed 6 years proves a high level of investments.

2. Investigations in farms in Przeworsk Province confirmed a varied level of energy equipment on example of tractors. Also, a high level of use of external funding sources including the Agency for Restructuring and Modernization of Agriculture at the purchase of these tractors. Mainly average and big farms showed great activity with regard to modernization of technical equipment. Thus, they cooperated with the Provincial Teams for Agricultural Advice.

3. The level of equipment in agricultural farms was high: All farms had at least one tractor, $87.1 \%$ two tractors and $29 \%$ of farms used three and more tractors. High number of tractors in comparison to the production scale which was statistically 2.26 tractors per a farm resulted mainly from the common usage of old vehicles. Users exploit old trac- 
tors for auxilliary works in farms and in the period when there is a lot of work due to the seasonality of agrotechnical treatments.

4. The power equipment level expressed with the power of engines in agricultural tractors was varied in relation to the farm area. The biggest group were farms with the power between 2 and $4 \mathrm{~kW} \cdot \mathrm{ha}^{-1}$ Almost every third farm had this index within 4 and $6 \mathrm{~kW} \cdot \mathrm{ha}$ ${ }^{1}$. In farms with a greater area of AL concentration of power decreased and the biggest farms had farms with the acreage of 10-20 ha. Almost fourfold difference in the level of energy saturation in the investigated group of farms which results from the number and power of tractors. Energy equipment of 8.1-8.4 $\mathrm{kW} \cdot \mathrm{ha}^{-1}$ determined in several farms should be deemed irrational.

\section{References}

Czarnocki, S., Wielogórska, G., Turska, E. (2011). Wpływ niektórych czynników na wiek ciągników i maszyn rolniczych w wybranych gospodarstwach środkowo-wschodniej Polski. Inżynieria Rolnicza, 9(134), 15-21.

Grześ, Z. (2008). Wpływ aktualizacji niektórych wskaźników eksploatacyjno-ekonomicznych na koszty eksploatacji ciągników rolniczych nowej generacji. Inżynieria Rolnicza, 2(100), 37-42.

Juściński, S. (2012a). An analysis of the new tractors distribution logistics in the aspect of the European Union programmes for supporting agriculture modernization, Journal of Central European Agriculture, 13(4), DOI: 10.5513/JCEA01/13.4.1140, 850-868.

Juściński, S. (2012b). The analysis of distribution logistics of new farm machines in the context of changes in the demand structure. Journal of Research and Applications in Agricultural Engineering, 57(2), 85-91.

Juściński S. Chomik Z. (2016). Regeneracja w naprawie pojazdów rolniczych, Monografia naukowa, Towarzystwo Wydawnictw Naukowych Libropolis, Lublin, ISBN 978-83-63761-67-7.

Juściński, S., Piekarski, W. (2008). Logistic systems in the management of agricultural tractors and machines' distribution, Acta Agrophisica, 12(1), 113-124.

Kapela, K., Czarnocki, S. (2011). Ocena wykorzystania ciągników rolniczych w gospodarstwach rodzinnych. Inżynieria Rolnicza, 9(134), 95-99.

Kocira, S., Parafiniuk S. (2006). Poziom i dynamika zmian wyposażenia i wykorzystania ciągników rolniczych w gospodarstwach rodzinnych. Inżynieria Rolnicza, 11(86), 169-175.

Kowalczyk, Z. (2008). Powierzchnia użytków rolnych a wyposażenie i wykorzystanie wybranych technicznych środków produkcji w gospodarstwach sadowniczych. Inżynieria Rolnicza, 6(104), 71-76.

Kowalik, I., Grześ, Z. (2006). Wpływ wykorzystania maszyn rolniczych na koszty mechanizacji w gospodarstwach rolniczych o różnej powierzchni. Inżynieria Rolnicza, 13(88), 201-208.

Kwaśniewski, D., Malaga-Toboła U., Kuboń, M. (2011). Ocena technicznych środków produkcji w gospodarstwach ekologicznych. Inżynieria Rolnicza, 7(132), 73-80.

Lorencowicz E. (2010). Okresy użytkowania ciągników i maszyn w wybranych gospodarstwach rodzinnych województwa lubelskiego. Inżynieria Rolnicza, 2(120), 27-32.

Lorencowicz, E. (2011). Rynek ciągników rolniczych w Polsce. Roczniki Naukowe Stowarzyszenia Ekonomistów Rolnictwa i Agrobiznesu, Tom XIII(3), 173-177.

Lorencowicz E. (2008). Zmiany w wyposażeniu technicznym wybranych gospodarstw rolnych po przystąpieniu polski do Unii Europejskiej. Inżynieria Rolnicza, 5(103), 73-79.

Malaga-Toboła, U. (2009). Produkcja towarowa a kierunki zmian wyposażenia technicznego w rozwojowych gospodarstwach rolnych. Inżynieria Rolnicza, 1(110), 175-182.

Pawlak, J. (2007). Wyposażenie rolnictwa polskiego w środki mechanizacji na tle wybranych krajów Unii Europejskiej. Inżynieria Rolnicza, 3(91), 151-158. 
Analysis of power...

Pawlak, J. (2011). Wyposażenie rolnictwa polskiego w środki mechanizacji w świetle wyników powszechnych spisów rolnych. Problemy Inżynierii Rolniczej, 4(74), 35-42.

Pawlak J. (2012). Zakupy ciągników rolniczych w Polsce w ujęciu regionalnym. Problemy Inżynierii, Rolniczej, 3(77), 35-44.

Piwowar, A. (2012). Wyposażenie gospodarstw w ciągniki w latach 1996-2010. Inżynieria Rolnicza, 4(139), 339-348.

Powszechny Spis Rolny (2002). (http://stat.gov.pl/spisy-powszechne/narodowe-spisypowszechne/powszechny-spis-rolny-2002/ciagniki-maszyny-i-inne-srodki-transportu-wgospodarstwach-rolnych,13,1.html)

Powszechny Spis Rolny (2010). (http://stat.gov.pl/obszary-tematyczne/rolnictwo-lesnictwo/psr2010/powszechny-spis-rolny-2010-srodki-produkcji-w-rolnictwie, 2,1.html).

Skudlarski, J. (2006). Optymalizacja decyzji zakupu maszyn rolniczych na przykładzie ciągników rolniczych, Inżynieria Rolnicza, 4(79), 173-180.

Szuk, T. (2009). Inwestycje maszynowe w wybranych gospodarstwach rolnych Dolnego Śląska. Inżynieria Rolnicza, 8(117), 199-206.

Tabor, S., Roczkowska-Chmaj, S. (2012). Plany modernizacji wyposażenia wybranych gospodarstw w ciągniki. Inżynieria Rolnicza, 4(140), 147-154.

Wasąg, Z., Tarasińska, J. (2010). Wstępna ocena rozwoju gospodarstw niskotowarowych w latach 2005-2008. Inżynieria Rolnicza, 4(122), 283-289.

Wójcicki, Z., Kurek J. (2011). Nakłady inwestycyjne w rozwojowych gospodarstwach rodzinnych. Problemy Inżynierii Rolniczej, 4(74), 5-11.

Wójcicki, Z. (2011). Projektowanie modernizacji gospodarstw rolnych. Problemy Inżynierii Rolniczej, 2(72), 5-16.

\section{ANALIZA POZIOMU WYPOSAŻENIA ENERGETYCZNEGO NA PRZYKŁADZIE CIĄGNIKÓW ROLNICZYCH W WYBRANYCH GOSPODARSTWACH POWIATU PRZEWORSKIEGO}

Streszczenie. Jednym z istotnych problemów współczesnej produkcji rolniczej są decyzje dotyczące inwestycji w ciągniki rolnicze. Zabezpieczenie sprawnej realizacji zabiegów agrotechnicznych i racjonalny poziom wykorzystania ciągników w aspekcie kosztów eksploatacji są pochodną posiadanego $\mathrm{w}$ gospodarstwach poziomu wyposażenia energetycznego. W pracy przeprowadzono badania 31 wybranych gospodarstw, które realizują produkcję na łącznym areale 937 ha użytków rolnych (UR) i eksploatują 70 ciągników. Analiza obejmowała informacje na temat: powierzchni gospodarstw, liczby i mocy użytkowanych ciągników, inwestycji w wyposażenie techniczne w zakresie zakupu ciągników rolniczych oraz profilu produkcji. W badanych gospodarstwach średnio na 100 ha powierzchni użytków rolnych przypadało 7,47 ciągników rolniczych, 90\% respondentów aktywnie korzystało z dopłat dostępnych w ramach funduszy strukturalnych z UE. Stwierdzono wysoki poziom wyposażenia energetycznego, szczególnie w gospodarstwach o mniejszym areale. Ponad 87\% gospodarstw użytkowało więcej niż jeden ciągnik, a wiek co trzeciego nie przekraczał 6 lat.

Słowa kluczowe: ciągnik rolniczy, poziom wyposażenia energetycznego 